\title{
A spontán intracranialis hypotensio diagnosztikája mágneses rezonanciás képalkotással
}

\author{
Magyar Máté dr. ${ }^{1,2,3}$ - Nyilas Nóra Luca dr. ${ }^{3}$ - Bereczki Dániel dr. ${ }^{1}$ \\ Bozsik György dr. ${ }^{1}$ - Rudas Gábor dr. ${ }^{3}$ - Ertsey Csaba dr. ${ }^{1}$ \\ Maurovich-Horvat Pál dr. ${ }^{4}$ - Barsi Péter dr. ${ }^{3}$ \\ ${ }^{1}$ Semmelweis Egyetem, Általános Orvostudományi Kar, Neurológiai Klinika, Budapest \\ ${ }^{2}$ Semmelweis Egyetem, Szentágothai János Idegtudományi Doktori Iskola, Budapest \\ ${ }^{3}$ Semmelweis Egyetem, Általános Orvostudományi Kar, Orvosi Képalkotó Klinika, \\ Neuroradiológia Tanszék, Budapest
}

${ }^{4}$ Semmelweis Egyetem, Általános Orvostudományi Kar, Orvosi Képalkotó Klinika, Radiológia Tanszék, Budapest

\begin{abstract}
A klasszikus esetben ortosztatikus fejájást okozó, spontán intracranialis hypotensiót az esetek túlnyomó többségében a gerinccsatornában, annak nyaki-háti átmenetében, illetve a háti szakaszán található liquorszivárgás okozza. Meglévő kötôszöveti betegség, degeneratív gerincbetegségek, illetve kisebb traumák szerepet játszhatnak a szivárgás kialakulásában. Az ortosztatikus fejfájás létrejöttében szerepet játszhat a meningealis szerkezetek, érzőidegek és hídvénák vongálódása. A klasszikus pozicionális, ortosztatikus fejfájásban szenvedő betegek körében gondolni kell a spontán intracranialis hypotensio lehetőségére, és az agykoponya, illetve a gerinc kontrasztanyaggal végzett mágneses rezonanciás vizsgálata (MRI) javasolt. A kontrasztanyaggal végzett koponya-MRI-vel klasszikus esetben diffúz, nem nodularis, intenzív, vaskos pachymeningealis kontrasztanyag-halmozás, kitágult vénássinus-rendszer, subduralis effusiók és az agytörzs caudalis diszlokációja („slumping”) látható. Fontos azonban szem előtt tartani, hogy az esetek 20\%-ában ezen eltérések nem detektálhatók. Jó minőségű, randomizált, kontrollált vizsgálatok nem történtek, a kezelés hagyományokon alapul. Kezdetben általában konzervatív terápiát alkalmaznak (ágynyugalom, koffein- és folyadékbevitel), ennek hatástalansága esetén epiduralis sajátvér-injekció, epiduralis fibrinragasztó-injektálás, illetve sebészi terápia jöhet szóba. Orv Hetil. 2021; 162(7): 246-251.
\end{abstract}

Kulcsszavak: fejfájás, intracranialis hypotensio, mágneses rezonanciás képalkotás

\section{Evaluation and diagnosis of spontaneous intracranial hypotension with magnetic resonance imaging}

Spontaneous intracranial hypotension, the classic feature of which is orthostatic headache, is most commonly caused by a cerebrospinal fluid leakage at the level of the spinal canal, in most cases at the thoracic level or cervicothoracic junction. Underlying connective tissue disorders, minor trauma, degenerative spinal diseases may play a role in the development of cerebrospinal fluid leaks. Traction on pain-sensitive intracranial and meningeal structures, particularly sensory nerves and bridging veins, may play a role in the development of orthostatic headache. In the case of patients with classic orthostatic headache, the possibility of spontaneous intracranial hypotension should be considered, and if suspected, brain magnetic resonance imaging (MRI) with gadolinium and additional spine MRI are recommended. Diffuse, non-nodular, intense, thick dural enhancement, subdural effusions, engorgement of cerebral venous sinuses, sagging of the brain are typical features on brain MRI, which, however, remain normal in up to 20 percent of patients with spontaneous intracranial hypotension. Unfortunately, no randomized clinical trials have evaluated the effectiveness of the various treatment strategies and no definitive treatment protocols have been established. In clinical practice, the first-line treatment of spontaneous intracranial hypotension is conservative (bed rest, caffeine and fluid intake). If conservative therapy is not effective, epidural blood patch, epidural fibrin glue, or surgical repair should be considered.

Keywords: headache, intracranial hypotension, magnetic resonance imaging

Magyar M, Nyilas NL, Bereczki D, Bozsik Gy, Rudas G, Ertsey Cs, Maurovich-Horvat P, Barsi P. [Evaluation and diagnosis of spontaneous intracranial hypotension with magnetic resonance imaging]. Orv Hetil. 2021; 162(7): 246-251

(Beérkezett: 2020. június 22.; elfogadva: 2020. augusztus 24.) 


\section{Rövidítések}

CT $=($ computed tomography) számítógépes tomográfia; EBP = (epidural blood patch $)$ epiduralis sajátvér-beadás; DTPA = (diethylenetriaminepentaacetic acid) dietilén-triamin-pentaecetsav; MRI = (magnetic resonance imaging $)$ mágneses rezonanciás képalkotás; SIH = spontán intracranialis hypotensio

A jelenleg spontán intracranialis hypotensiónak $(\mathrm{SIH})$ nevezett kórkép korábban többek között liquorhypotensiós fejájás, liquorhypovolaemiához társuló fejfájás, liquorszivárgáshoz társuló fejfájás néven is ismert volt. A SIH incidenciája egy 2006-ban megjelent összefoglaló közlemény alapján 5/100 000 lakos/év, a csúcsincidencia 40 éves kor körül figyelhető meg; a nők kétszer gyakrabban érintettek, mint a férfiak [1]. Patogenezisének lényege a liquorszivárgás, amely a liquor mennyiségének, nyomásának, illetve az agyra gyakorolt felhajtóerejének csökkenését okozza. Ebben az esetben az agy a koponyaalapra süllyed, az agyat rögzító és ellátó struktúrák (agyburkok, érzőidegek, hídvénák) vongálódnak [2], és ez a vongálódás okozza a kórkép vezetô tünetét, az ortosztatikus fejfájást. A fejfájás kialakulásához hozzájárul továbbá, hogy a Monro-Kelly-doktrínának megfelelően a liquor mennyiségének csökkenése miatt a vér mennyiségének és ezáltal az agyi erek körfogatának növekednie kell. Az utóbbi mechanizmust támasztja alá az a megfigyelés, hogy a vena jugularis kompressziójának hatására a kórképben szenvedő betegek fejfájása súlyosbodik [2].

SIH esetén neurológiai fizikális vizsgálattal általában nem lehet kóros eltérést észlelni $[2,3]$.

Felnőtt emberben egy nap átlagosan $500 \mathrm{ml}$ liquor termelődik, amelynek 75\%-át a plexus chorioideus termeli, a maradék 25\%-ot pedig az ependymán keresztül a kamrákba belépő agyi kapillárisok szekretálják. A liquor felszívódása nagy részben a vénás sinusokban a villi arachnoidaleson keresztül valósul meg [4].

Jelen tudásunk szerint a SIH kóreredete az arachnoidealis membrán és a dura szakadása, melynek következménye a gerinccsatornából való liquorszivárgás [5]. Meglévő kötőszöveti betegség (Ehlers-Danlos-, Marfan-szindróma) rizikófaktort jelent a kórkép kialakulására, tekintettel arra, hogy a dura sérülékenységét is okozza [6-8]. Az arachnoidealis membránnak, illetve a durának a sérülését egyszerú traumák is okozhatják. A leggyakoribb esetben a nyaki-háti gerincszakasz hirtelen nyújtó, csavaró mozdulata, tüsszentés, szexuális aktus [9], amelyek az esetek döntő többségében a háti gerincen vagy a háti-nyaki gerincátmeneten, ritkább esetben a koponyaalapon hoznak létre liquorszivárgást, ám a koponyaalapon kialakult liquorszivárgás oki szerepe a SIH kialakulásában kérdéses [10]. Ezek a kis traumás események az epiduralis cysták (amelyek a fetalis fejlődés alatt alakultak ki), a perineuralis (Tarlov-) cysták vagy az ideghüvely duraborításának szakadásán keresztül idézhetnek elő liquorszivárgást [5]. Degeneratív gerincbetegségek, ossealis felrakódások mechanikus irritáción keresztül hozhatnak létre duralis sérülést és ezáltal liquorszivárgást $[11,12]$. Ritka esetekben spontán spinalis liquor-venosus fistula is állhat a kórkép hátterében, ekkor a subarachnoidealis tér felől a liquor direkt összeköttetésbe kerül a spinalis epiduralis vénákkal $[13,14]$.

\section{Klinikai megjelenés}

A kórkép vezetô tünete, az ortosztatikus fejfájás [15] kialakulhat hirtelen vagy fokozatosan, felülést vagy felállást követóen, a legtöbbször pár percen belül, de egyes esetekben lassabban, akár órák alatt [16]. Ritkán heves, „thunderclap" (villámcsapásszerú) fejfájás képét is utánozhatja [17]. Felállás, fejmozdítás, erőlködés, orrfújás, köhögés, tüsszentés, a vena jugularis kompressziója fokozza a fájdalmat [1]. A fejfájás nyomó vagy lüktető jellegü, az enyhétől az egészen bénító súlyosságig terjedő erősségú lehet [1]. A betegek gyakrabban jeleznek homloktáji, mint occipitalis vagy diffúz fájdalmat [9]. Lefekvés hatására a fejfájás általában percek alatt mérséklődik [18].

A kórképet domináló ortosztatikus fejfájáshoz további panaszok és tünetek társulhatnak, mint például nyaki fájdalom és merevség, hányinger, hányás, fülcsengés, forgó szédülés, homályos látás, kettős látás, fényérzékenység [1]. Ritkább esetekben a hypophysis érintettsége miatt hyperprolactinaemia és galactorrhoea [19], a kisagyi hídvénák sérülése miatt kisagyi vérzés társulhat a kórképhez [20].

Tekintettel arra, hogy a fejfájás gyakori panasz, illetve mivel a neurológiai vizsgálat során kórjelző fizikális eltérés a SIH esetében nem található [3], a kórképet gyakran nem ismerik fel [21]. Minden olyan beteg esetében, aki ortosztatikus fejfájásra panaszkodik, gondolni kell a spontán inctracranialis hypotensio lehetőségére. Ez alól

1. táblázat | Koponya-MRI során látható eltérések SIH esetén [23-28]

Diffúz, nem nodularis, intenzív, vaskos pachymeningealis kontrasztanyag-halmozás (2. ábra). Az intenzív halmozás idővel elmúlik, annak ellenére, hogy a hypotensio krónikus formában megmarad $[23]$

Subduralis hygroma [24], illetve 1. és 2. ábra

Subduralis haematoma (ritkábban), feltételezhetően a hídvénák sérülésének következtében (akár subarachnoidealis vérzést vagy superficialis siderosist is okozhat) $[23,25]$

Az agy craniocaudalis irányú lesüllyedése $\rightarrow$ a pons-mesencephalon szög lecsökken $\left(<50^{\circ}\right)$, a pontomamillaris távolság lecsökken $(<5,5 \mathrm{~mm})$, elörehaladott állapotban transtentorialis uncus vagy kisagyi tonsillaris beékelődés is kialakulhat [26]

A vénás sinusok kitágulása (3. ábra) [27]

A hypophysis megnagyobbodása (4. ábra), melyre a hypothalamus és a látóideg-kereszteződés ráfekszik [28]

A basalis cisternák és kamrák megkisebbedése [24]

MRI = mágneses rezonanciás képalkotás; $\mathrm{SIH}=$ spontán intracranialis hypotensio 
Extraarachnoidealis folyadékgyülemek [24]

Az epiduralis vénás plexusok kitágulása, ami a canalis spinalist akár szúkítheti is (ritkán akár myelon- vagy gyöki kompressziót is okozhat kamrai söntös betegeken, mely a szakirodalomban Miyazaki-szindrómaként ismert) [29]

Extraduralis folyadék-extravasatio [30, 31]

$\mathrm{MRI}=$ mágneses rezonanciás képalkotás; $\mathrm{SIH}=$ spontán intracranialis hypotensio

kivétel, ha lumbalpunctio vagy más, iatrogén liquorcsorgást képző beavatkozás előzte meg a panasz kialakulását (például a koponyaalapot is érintő, rosszindulatú sinonasalis daganatok endoszkópos transcribriform feltárását követően egyes esetekben liquorrhoea alakulhat ki [22]).

\section{Diagnosztika}

SIH fennállásának lehetősége esetén a koponyának gadolínium kontrasztanyaggal végzett, illetve a teljes gerincnek natív és kontrasztanyaggal végzett mágneses rezonanciás vizsgálata (MRI) javasolt, egyrészt a liquorhypotensio következményeinek (1. és 2. táblázat) [23-31], másrészt a liquorszivárgásnak és az azt okozó gerincpatológiának (például meningealis diverticulum) az azonosítására [32]. A SIH esetén gadolínium kontrasztanyagos koponya-MRI-vel látható, a liquorhypotensio következtében kialakult, jellemző eltéréseket saját, válogatott képanyaggal ábrázoljuk (1-4. ábra). A koponya-CT diagnosztikus értéke ebben a kórképben korlátozott [1].

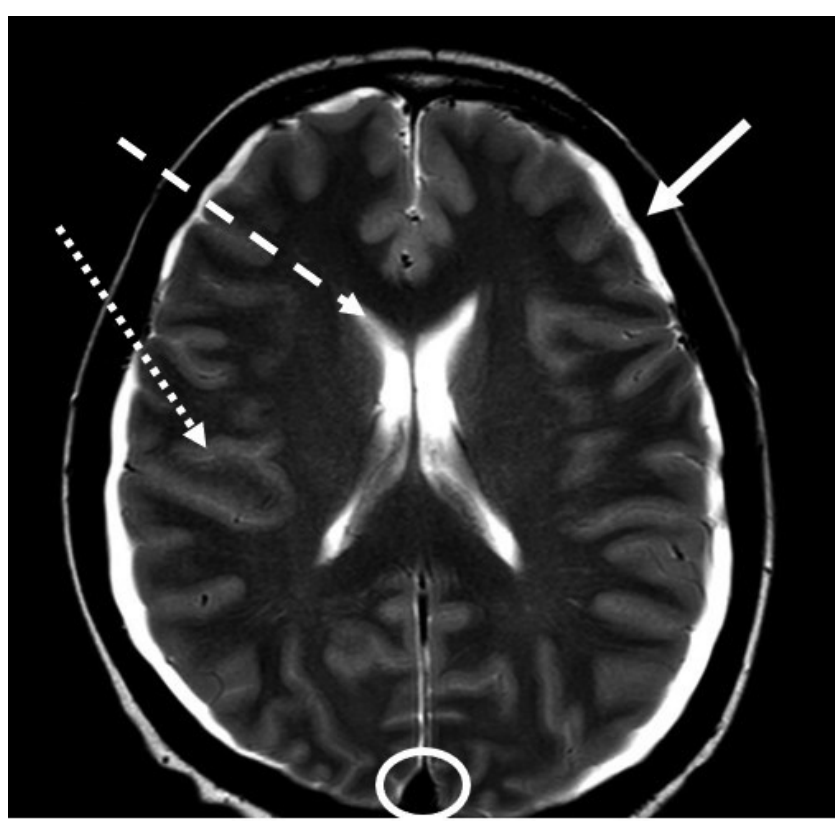

1. ábra

Axialis T2-felvétel: kétoldali, 4-5 mm vastagságú subduralis effusio (folytonos nyíl), a sulcusok beszúkülése (pontozott nyíl) és keskeny kamrák (szaggatott nyíl), valamint kissé tágabb sinus sagittalis superior (fehér karika)

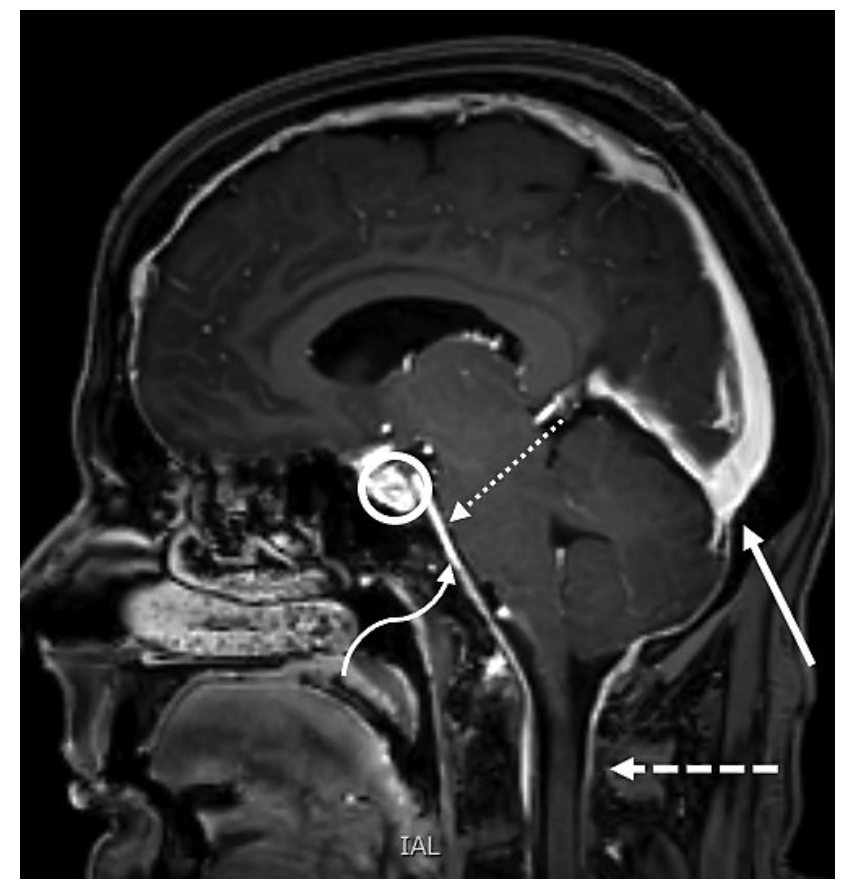

3. ábra

Posztkontrasztos sagittalis Tl-felvétel: tágult vénás sinusok (nyíl), az átlagosnál kifejezettebb duralis kontrasztanyag-halmozás spinalisan is (szaggatott nyíl). Megsüllyedt agy, szúk basalis cisternák (pontozott nyíl), duzzadt hypophysis (bekarikázva), szélesebb retroclivalis plexus (görbe nyíl)

Az MRI-lehetőségek elterjedése, illetve az MRI-k során észlelt eltéréseknek a kórképpel való társítása előtt a SIH gyakran nem került felismerésre. A diagnózisalkotás jelenleg sem egyszerú, a betegek közel 20\%-ában nem 


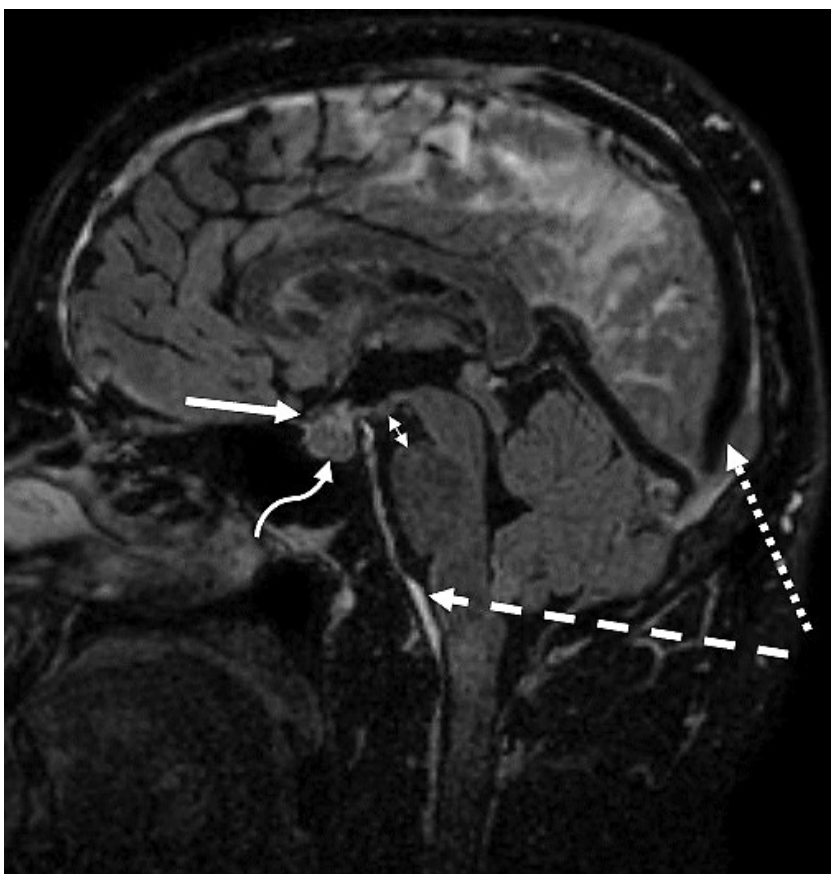

4. ábra

Kontrasztos sagittalis FLAIR-felvétel: a hypophysis megnagyob bodása (görbe nyíl), az agy megsüllyedt, a pontomamillaris távolság a normálérték felső határán (kettősnyíl: kb. 5,5 mm) Vaskos hypophysisnyél és chiasma ráfekszik a dorsum sellaere (folytonos nyíl). Prominens vénás sinusok (pontozott nyíl) és tágabb retroclivalis plexus (szaggatott nyíl)

látható kóros eltérés a gadolíniummal végzett koponyaMRI során [1]. Egy tanulmány a koponya-MRI szenzitivitását 83\%-osnak, a gerinc-MRI szenzitivitását 94\%-osnak értékelte [33].

Egyes vizsgálatok bizonyították, hogy a kontrasztanyag nélkül végzett, tehát nem invazív, erősen T2-súlyozott, ún. MRI-mielográfiás szekvencia a rutin-CT-mielográfia alternatívája lehet a liquorszivárgás szintjének megállapításában, valamint a meningealis diverticulum kimutatásában [34]. Az intrathecalis gadolíniummal végzett kontrasztos, Tl-zsírszuppressziós MRI-mielográfia szintén kiváló, egy 2014-es vizsgálat alapján a CTmielográfiánál érzékenyebb diagnosztikus lehetőség a liquorszivárgás kimutatására, lokalizációjára [35].

A liquorszivárgás legmegbízhatóbb kimutatási és lokalizációs módszere a CT-mielográfia, illetve a dinamikus CT-mielográfia [24]. A dinamikus CT-mielográfia során a felvételeket az intrathecalis kontrasztanyag-beadás alatt készítik: ezzel az időbeli felbontóképesség javul a rutinCT-mielográfiához képest, amikor is az intrathecalis kontrasztanyagot a betegnek a CT-vizsgálóberendezésbe való behelyezése előtt adják be. A dinamikus CT-mielográfia hatékonyabb a gyors áramlású liquorelfolyási helyek kimutatásában, mint a rutin-CT-mielográfia [24]. Mind a CT-mielográfia, mind pedig a gadolíniummal végzett MRI-mielográfia esetén lehetőség van intrathecalisan adott kontrasztanyag és sóoldat keverékével pozitív nyomással elvégezni a vizsgálatokat és így elősegíteni a liquorkilépés helyének azonosítását [13, 36, 37].
A gyors elfolyású liquorszivárgás helyének felismerésében egyes esetekben a CT- és az MRI-mielográfia időbeli felbontóképessége nem elég nagy [38], a digitális szubtrakciós mielográfia időbeli felbontóképessége ezzel ellentétben elég nagy ahhoz, hogy a gyors elfolyású liquorszivárgások, illetve a direkt spinalis liquor-venosus fistulák detektálhatók legyenek [13, 14]. Ezen vizsgálóeljárás során az átvilágító asztalon fekvő beteget az intrathecalis kontrasztanyag-beadást követően, az asztal mozgatásával Trendelenburg -pozícióba állítják, és követik a kontrasztanyag „oszlopának” mozgását. A kontrasztanyag extrathecalis megjelenése liquorszivárgásra utal, amely még látványosabbá tehető digitális szubtrakció használatával [39].

Abban az esetben, ha a betegnek kifejezett ortosztatikus fejfájása van, és a fenti vizsgálóeljárásokkal a kórképet igazolni nem sikerült, a radioizotóp-ciszternográfia elvégzése vezethet eredményre, amely vizsgálóeljárás a liquorszivárgás pontos helyének meghatározásában is hasznos [40]. A vizsgálatot intrathecalisan beadott radioizotóppal (indium-111-DTPA) végzik, és az izotóp beadását követóen az izotóp eloszlását előre meghatározott időközönként (például 6 óránként), 24-48 órán át vizsgálják. Fiziológiás állapotban az izotóp a beadás helyétől az agy irányába áramlik, így a liquorcsorgás legnyilvánvalóbb indirekt jele a konvexitás felett nem vagy csak csekély mértékben detektálható aktivitás [40]. Meglehetősen csekély a liquorszivárgás lehetősége, amennyiben az első 24 órában a konvexitás felett normális radioaktivitás detektálható [40].

További diagnosztikus eljárás a diagnosztikus lumbalpunctio, amelynek során a nyitási nyomás értéke $(<5$ Hgmm) diagnosztikus lehet SIH esetén [41]. Amennyiben a diagnózist egyéb képalkotó eljárások, például MRI-k már igazolták, a lumbalpunctio végzése nem ad további információt, ezért kerülendő. A kórképben gyújtött liquor víztiszta és színtelen, a liquor mikrobiológiai és citológiai vizsgálatok sosem kórosak, és a liquorcukorszint sohasem alacsony $[3,42]$.

Az invazív vizsgálóeljárások hátránya a lumbalpunctio következtében esetlegesen kialakuló liquorszivárgás, amely a beteg tüneteit súlyosbíthatja.

\section{Terápia}

A betegek egy részében a liquorszivárgás spontán gyógyul a tünetek kezdetét követően 1-2 hét alatt, és így a betegek tünetmentessé válhatnak, és további terápiás beavatkozás nem szükséges [43].

Amennyiben a beteg állapota spontán módon nem javult, számos terápiás lehetőség áll rendelkezésre, azonban a terápiás módszerek értékelésére irányuló randomizált klinikai vizsgálatok nem történtek ez idáig.

A konzervatív terápia része a szigorú ágynyugalom, orális vagy intravénás folyadékbevitel, amely a liquor mennyiségének helyreállítását célozza, illetve a koffein- 
vagy teofillinbevitel, ám ezek hatékonysága nincs alátámasztva $[1,2,44]$.

A konzervatív terápiára nem reagáló betegek esetében epiduralis sajátvér-beadás (EBP - epidural blood patch) javasolt $[24,45]$. A kezelés során 10-20 ml saját vért juttatnak az epiduralis térbe. Amennyiben az első EBP nem sikeres, ismételt, nagyobb mennyiség $(20-100 \mathrm{ml})$ adása is szükséges lehet [24]. Az EBP hatásmechanizmusa nem teljesen ismert, de a vezetó hipotézis az, hogy az EBP egyrészt tamponálja a duralis liquorszivárgást, másrészt a durára kifejtett nyomással megemeli a gerincvelői liquornyomást, aminek következtében áttételesen a liquorhypotensio intracranialisan mérséklődik [45].

Az EBP eredménytelensége esetén alkalmazott epiduralis fibrinragasztó-, illetve sebészi kezelés a szivárgás definitív lokalizációját kívánja meg, amelyet a fent leírtaknak megfelelően CT-mielográfiával vagy - ritkábban - radioizotóp-ciszternográfiával lehet meghatározni. Egyes vizsgálatok igazolták, hogy azon betegek egyharmadában, akiknél az EBP nem volt hatásos, epiduralis fibrinragasztó-terápiával a sebészeti beavatkozás elkerülhető volt [46]. Amennyiben az előzőekben részletezett terápiás eljárások sikertelennek bizonyultak, sebészeti kezelés során a meningealis diverticulumokat vagy egyéb duralis sérüléseket suturával vagy fémklippel zárják [1].

A kortikoszteroidok hatékonysága a SIH tüneteinek kontrollálásában vitatott, amennyiben effektívek, csak részleges és rövid távú a hatásuk. A hosszú távú kortikoszteroidterápia a mellékhatásai miatt nem alkalmazható [44].

\section{Kórlefolyás}

A SIH hosszú távú lefolyására vonatkozóan kevés adat áll rendelkezésre; Schievink és mtsai összefoglaló közleménye alapján az esetek körülbelül 10\%-ában újul ki, függetlenül a terápiás beavatkozástól, illetve annak módjától [1].

Sikeres terápiát követően a betegek egy része eltérő fejfájásról számolhat be, amely épp az ellentéte a SIHhez társuló fejfájásnak: alvásból felébreszti a beteget, felüléskor, felálláskor a fájdalom erőssége mérséklődik, hányingerrel, hányással járhat. Ezek a tünetek megemelkedett intracranialis nyomáshoz társulnak, amelyet rebound intracranialis nyomásemelkedésnek neveznek. Ennek hátterében a liquorszivárgás miatti, átmeneti fokozott liquortermelést valószínúsítik, amely a sikeres terápiás beavatkozás után csak hetekkel vagy hónapokkal normalizálódik [17, 39, 40].

Azon betegeknek, akiknek a liquorszivárgást igazoltan megoldó terápiás beavatkozást követően is perzisztáló tüneteik vannak, valószínúleg residualisan megváltozott liquordinamika vagy a jelen vizsgálómódszerekkel nem kimutatható kis, residualis liquorszivárgások okozzák a tüneteit [1].

\section{Következtetés}

A vezető tünetként ortosztatikus fejfájást [15] okozó SIH incidenciája a fiatal-középkorú betegek körében fordul elő a legmagasabb arányban; nőknél kétszer gyakoribb, mint férfiaknál [1]. Fizikális vizsgálattal neurológiai kórjelző eltérés hiányában gyakran nem ismerik fel [21], azonban új keletü, mindennapos fejfájás hátterében gondolni kell erre a kórképre [1]. A kórkép oka az esetek többségében a gerinccsatornában található liquorszivárgás [2], amelynek kialakulásában kötőszöveti betegség $[6,7]$, degeneratív gerincbetegségek [11, 12], illetve trauma $[5,10]$ játszhat szerepet. SIH fennállásának lehetősége esetén kontrasztanyagos koponya-MRI-t és egy ülésben kontrasztanyagos teljesgerinc-MRI-t ajánlott végezni [32] a liquorszivárgás helyének és okának, illetve következményeinek megítélésére. A kórkép kezelése javarészt hagyományokon alapul; kezdetben általában konzervatív terápia jön szóba (ágynyugalom, koffein- és folyadékbevitel) [1, 2], amelynek hatástalansága esetén epiduralis EBP [45], epiduralis fibrinragasztó-injektálás, illetve sebészi terápia [46] alkalmazható.

Anyagi támogatás: A közlemény megírásához a szerzők anyagi támogatásban nem részesültek.

Szerzői munkamegosztás: Irodalmi áttekintés: M. M., Ny. N. L., B. P., E. Cs., B. Gy. A kézirat megírása: M. M., Ny. N. L., B. P., B. D. A cikk végső áttekintése: E. Cs., B. D., B. Gy., R. G., B. P., Ny. N. L., M. M., M.-H. P. A képanyag kiválasztása: B. P., R. G., Ny. N. L. A cikk végleges változatát valamennyi szerző elolvasta és jóváhagyta.

Érdekeltségek: A szerzőknek a cikk megírására hatással levő pénzügyi érdekeltségei a cikk megírását megelőző három évben nem voltak.

\section{Irodalom}

[1] Schievink WI. Spontaneous spinal cerebrospinal fluid leaks and intracranial hypotension. JAMA 2006; 295: 2286-2296.

[2] Marcelis J, Silberstein SD. Spontaneous low cerebrospinal fluid pressure headache. Headache 1990; 30: 192-196.

[3] Rando TA, Fishman RA. Spontaneous intracranial hypotension: report of two cases and review of the literature. Neurology 1992; 42: $481-487$

[4] Sakka L, Coll G, Chazal J. Anatomy and physiology of cerebrospinal fluid. Eur Ann Otorhinolaryngol Head Neck Dis. 2011; 128: 309-316.

[5] Lasater GM. Primary intracranial hypotension. The low spinal fluid pressure syndrome. Headache 1970; 10: 63-66.

[6] Mokri B, Maher CO, Sencakova D. Spontaneous CSF leaks: underlying disorder of connective tissue. Neurology 2002; 58: 814-816.

[7] Ferrante E, Citterio A, Savino A, et al. Postural headache in a patient with Marfan's syndrome. Cephalalgia 2003; 23: 552555.

[8] Ralovich FV, Kiss N, Horváth K, et al. Up-to-date classification and multidisciplinary symptoms of Ehlers-Danlos syndromes. 
[Az Ehlers-Danlos-szindrómák korszerú osztályozása és multidiszciplináris tünettana.] Orv Hetil. 2019; 160: 603-612. [Hungarian]

[9] Lay CM. Low cerebrospinal fluid pressure headache. Curr Treat Options Neurol. 2002; 4: 357-363.

[10] Schievink WI, Schwartz MS, Maya MM, et al. Lack of causal association between spontaneous intracranial hypotension and cranial cerebrospinal fluid leaks. J Neurosurg. 2012; 116: 749-754.

[11] Vishteh AG, Schievink WI, Baskin JJ, et al. Cervical bone spur presenting with spontaneous intracranial hypotension. Case report. J Neurosurg. 1998; 89: 483-484.

[12] Eross EJ, Dodick DW, Nelson KD, et al. Orthostatic headache syndrome with CSF leak secondary to bony pathology of the cervical spine. Cephalalgia 2002; 22: 439-443.

[13] Kumar N, Diehn FE, Carr CM, et al. Spinal CSF venous fistula: a treatable etiology for CSF leaks in craniospinal hypovolemia. Neurology 2016; 86: 2310-2312.

[14] Schievink WI, Moser FG, Maya MM. CSF-venous fistula in spontaneous intracranial hypotension. Neurology 2014; 83: $472-473$.

[15] Szirmai I. (ed.) Neurology. [Neurológia.] Medicina Könyvkiadó, Budapest, 2017. [Hungarian]

[16] Mea E, Chiapparini L, Savoiardo M, et al. Application of IHS criteria to headache attributed to spontaneous intracranial hypotension in a large population. Cephalalgia 2009; 29: 418-422.

[17] Grimaldi D, Mea E, Chiapparini L, et al. Spontaneous low cerebrospinal pressure: a mini review. Neurol Sci. 2004; 25(Suppl 3): S135-S137.

[18] Schievink WI. Headache relief from lateralizing head and neck positions in spontaneous intracranial hypotension. Neurology 2011; 77: 799-800

[19] Schievink WI, Nuño M, Rozen TD, et al. Hyperprolactinemia due to spontaneous intracranial hypotension. J Neurosurg. 2015; 122: 1020-1025.

[20] Schievink WI, Maya MM, Nuño M. Chronic cerebellar hemorrhage in spontaneous intracranial hypotension: association with ventral spinal cerebrospinal fluid leaks: clinical article. J Neurosurg Spine 2011; 15: 433-440.

[21] Schievink WI. Misdiagnosis of spontaneous intracranial hypotension. Arch Neurol. 2003; 60: 1713-1718.

[22] Piski Z, Büki A, Gerlinger I, et al. Minimally invasive endoscopic transcribriform resection of malignant lesions of the skull base. [Minimálisan invazív, endoszkóppal asszisztált, transcribriform reszekció a koponyaalap rosszindulatú daganatainak sebészetében.] Orv Hetil. 2019; 160: 1584-1590. [Hungarian]

[23] Spelle L, Boulin A, Tainturier C, et al. Neuroimaging features of spontaneous intracranial hypotension. Neuroradiology 2001; 43: 622-627.

[24] Ferrante E, Trimboli M, Rubino F. Spontaneous intracranial hypotension: review and expert opinion. Acta Neurol Belg. 2020; 120: 9-18.

[25] Chung SJ, Lee JH, Kim SJ, et al. Subdural hematoma in spontaneous CSF hypovolemia. Neurology 2006; 67: 1088-1089.

[26] Atkinson JL, Weinshenker BG, Miller GM, et al. Acquired Chiari I malformation secondary to spontaneous spinal cerebrospinal fluid leakage and chronic intracranial hypotension syndrome in seven cases. J Neurosurg. 1998; 88: 237-242.

[27] Bakshi R, Mechtler LL, Kamran S, et al. MRI findings in lumbar puncture headache syndrome: abnormal dural-meningeal and dural venous sinus enhancement. Clin Imaging 1999; 23: $73-$ 76.
[28] Alvarez-Linera J, Escribano J, Benito-León J, et al. Pituitary en largement in patients with intracranial hypotension syndrome. Neurology 2000; 55: 1895-1897.

[29] Várallyay P, Nagy Z, Szúcs A, et al. Miyazaki syndrome: cervical myelo/radiculopathy caused by overshunting. A systematic review. Clin Neurol Neurosurg. 2019; 186: 105531.

[30] Mokri B. Low cerebrospinal fluid pressure syndromes. Neurol Clin. 2004; 22: 55-74

[31] Starling A, Hernandez F, Hoxworth JM, et al. Sensitivity of MRI of the spine compared with CT myelography in orthostatic headache with CSF leak. Neurology 2013; 81: 1789-1792.

[32] Medina JH, Abrams K, Falcone S, et al. Spinal imaging findings in spontaneous intracranial hypotension. Am J Roentgenol. 2010; 195: 459-464.

[33] Watanabe A, Horikoshi T, Uchida M, et al. Diagnostic value of spinal MR imaging in spontaneous intracranial hypotension syndrome. Am J Neuroradiol. 2009; 30: 147-151.

[34] Wang YF, Lirng JF, Fuh JL, et al. Heavily T2-weighted MR myelography vs CT myelography in spontaneous intracranial hypotension. Neurology 2009; 73: 1892-1898.

[35] Chazen JL, Talbott JF, Lantos JE, et al. MR myelography for identification of spinal CSF leak in spontaneous intracranial hypotension. Am J Neuroradiol. 2014; 35: 2007-2012.

[36] Griauzde J, Gemmete JJ, Pandey AS, et al. Intrathecal preservative-free normal saline challenge magnetic resonance myelography for the identification of cerebrospinal fluid leaks in spontaneous intracranial hypotension. J Neurosurg. 2015; 123: 732-736.

[37] Gatica-Moris SR, Welch TL, Abcejo AS, et al. Anesthesia during positive-pressure myelogram: a new role for cerebral oximetry. J Neurosurg Anesthesiol. 2019 Oct 23. Doi: 10.1097/ ANA.0000000000000651. [Online ahead of print]

[38] Schievink WI. Novel neuroimaging modalities in the evaluation of spontaneous cerebrospinal fluid leaks. Curr Neurol Neurosci Rep. 2013; 13: 358.

[39] Kranz PG, Luetmer PH, Diehn FE, et al. Myelographic techniques for the detection of spinal CSF leaks in spontaneous intracranial hypotension. Am J Roentgenol. 2016; 206: 8-19.

[40] Mokri B. Radioisotope cisternography in spontaneous CSF leaks: interpretations and misinterpretations. Headache 2014; 54: $1358-1368$.

[41] Lipman IJ. Primary intracranial hypotension: the syndrome of spontaneous low cerebospinal fluid pressure with traction headache. Dis Nerv Syst. 1977; 38: 212-213.

[42] Mokri B, Piepgras DG, Miller GM. Syndrome of orthostatic headaches and diffuse pachymeningeal gadolinium enhancement. Mayo Clin Proc. 1997; 72: 400-413.

[43] Hochman MS, Naidich TP, Kobetz SA, et al. Spontaneous intracranial hypotension with pachymeningeal enhancement on MRI. Neurology 1992; 42: 1628-1630.

[44] Mokri B. Spontaneous low pressure, low CSF volume headaches: spontaneous CSF leaks. Headache 2013; 53: 1034-1053.

[45] Duffy PJ, Crosby ET. The epidural blood patch. Resolving the controversies. Can J Anaesth. 1999; 46: 878-886.

[46] Schievink WI, Maya MM, Moser FM. Treatment of spontaneous intracranial hypotension with percutaneous placement of a fibrin sealant. Report of four cases. J Neurosurg. 2004; 100: 10981100 .

(Magyar Máté dr.,

Budapest, Balassa J. u. 6., 1083

e-mail: magyar.mate@med.semmelweis-univ.hu)

A cikk a Creative Commons Attribution 4.0 International License (https://creativecommons.org/licenses/by/4.0/) feltételei szerint publikált Open Access közlemény, melynek szellemében a cikk bármilyen médiumban szabadon felhasználható, megosztható és újraközölhetö, feltéve, hogy az eredeti szerző és a közlés helye, illetve a CC License linkje és az esetlegesen végrehajtott módosítások feltüntetésre kerülnek. (SID_1) 